\title{
CYCLIC. DISULFIDE- AND DITHIOETHER-CONTAINING OPIOID TETRAPEPTIDES: DEVELOPMENT OF A LIGAND WITH HIGH DELTA OPIOID RECEPTOR SELECTIVITY AND AFFINITY
}

\author{
Henry I. Mosberg, John R. Omnaas, Fedor Medzihradsky, and
}

Charles B. Smith

College of Pharmacy ( H.I.M., J.R.O. ), Department of Biological Chemistry (F.M. ), and Department of Pharmacology (F.M., C.B.S. ), The University of Michlgan, Ann Arbor, MI 48109

\author{
(Recelved in final form August 5, 1988)
}

\section{Summary}

Tetrapeptldes of primary sequence Tyr-X-Phe-YNH ${ }_{2}$, where $X$ is D-Cys or D-Pen (penicillamine) and where $Y$ is D-Pen or L-Pen, were prepared and were cyclized via the side chain sulfurs of residues 2 and 4 to disulfide or dithioether-containing analogs. These peptldes are related to previously reported penicillamine-containing pentapeptide enkephalin analogs but lack the central glycine residue of the latter and were designed to assess the effect of decreased ring size on opioid activity. Binding affinities of the tetrapeptides were determined to both $\mu$ and $\delta$ oploid receptors. Binding affinity and selectivity in the tetrapeptide serles were observed to be highly dependent on primary sequence. For example, L-Pen analogs displayed low affinity and were nonselective, while the corresponding D-Pen ${ }^{4}$ dlastereomers were of variable affinity and higher selectivity. Among the latter compounds were examples of potent analogs in which selectivity shifted from $\delta$ selective to $\mu$ selective as the ring size was increased. The relatively high binding affinity and $\delta$ receptor selectlvity observed with one of the carboxamide terminal disulfide analogs led to the synthesis of the corresponding carboxylic acid terminal, Tyr-D-Cys-Phe-D-PenOH. This analog displayed $\delta$ receptor binding selectlvity similar to that of the standard $\delta$ ligand, [DPen ${ }^{2}, \mathrm{D}-\mathrm{Pen} \mathrm{n}^{5}$ jenkephalin (DPDPE), and was found to have a 3.5-fold higher binding affinity than DPDPE. All the tetrapeptides were further evaluated in the isolated mouse vas deferens ( $m v d$ ) assay and all displayed opioid agonist actlvity. In general, tetrapeptide potencies in the mouse vas deferens correlated well with binding affinities but were somewhat lower. Receptor selectivity in the mvd, assessed by examining the effect of opioid antagonists on the tetrapeptide concentration-effect curves, was similar to that determined in the binding studies.

We have previously described (1-3) a series of enkephalin analogs of the general structure:

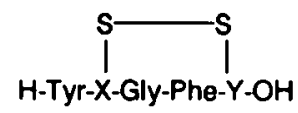

in which

$$
\begin{aligned}
& X=D \text {-Cys or } \quad D-P e n \\
& Y=D(\text { or } L) \text {-Cys or } D(\text { or } L)-P e n
\end{aligned}
$$

where Pen, penicillamine, is $\beta, \beta$-dimethyicysteine. These analogs, which are conformationally restricted because of the imposed cyclization through the side chain sulfurs and are further restricted because of the rigidizing effect of the penicillamine gem dimethyl groups (1), are notable for their high degree of selectivity

$$
\begin{array}{cl}
0024-3205 / 88 & \$ 3.00+.00 \\
\text { Copyrtght (c) } 1988 \text { Pergamon Press plc }
\end{array}
$$


for the $\delta$ oploid receptor. The bls-penlcillamine analogs within this series, [D-Pen ${ }^{2}$, D-Pen ${ }^{5}$ ]enkephalin (DPDPE) and [D-Pen ${ }^{2}$ L-Pen ${ }^{5}$ ]enkephalln (DPLPE) display the highest selectlvity yef reported for the $\delta$ receptor, while those analogs with a single pentclltamine residue, such as [D-Pen ${ }^{2}, L-C y s$ ] (DPLCE) and [D-Cys ${ }^{2}, D-P e n^{5}$ ]enkephalin (DCDPE), are less selective but are more potent. More recently we have examined the effect of ing size on opiold actuity for the bis-penicilamine analogs by means of the dithloether-containing serles:

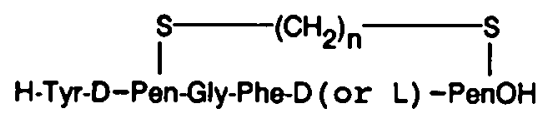

In this series $\delta$ receptor binding afflinty and selectlvity were observed to decrease with increasing ring size (4).

Schiller and coworkers have reported a series of smaller, cyclic des-Gly ${ }^{3}$ enkephalin tetrapeptides in which cyclization is effected by amide bond formation via side chain functions of residues 2 and $4(5,6)$. Whin this series are members which display considerable $\mu$ opioid receptor selectlvity resulting primarily from reduced $\delta$ receptor affinity. In view of this finding and our studles on expanded ring size in the pentapeptide serles, we undertook an Imvestlgatlon of the effect of ring contraction on oploid receptor affinity and selecthity in a serles of des-Gly ${ }^{3}$ disulfide-and dithioether-containing tetrapeptides of general structure:

where $\quad \begin{aligned}\left.H-T y r-X-P h e-Y \cdot \mathrm{NH}_{2} \text { (or }-\mathrm{OH}\right) \\ \begin{aligned} X & =\mathrm{D} \text {-Cys or D-Pen } \\ Y & =\mathrm{D} \text {-(or L-)Pen } \\ n & =0,1,2,3\end{aligned}\end{aligned}$

Several analogs in this serles have interesting oploid receptor binding proflles. Particularly noteworthy among these is an analog which exhiblts higher $\delta$ receptor affinity than the bis-penicillamine enkephalins whlle maintaining comparable selecthity.

\section{Methods}

Peptide symthesis. All peptides reported here were prepared by solid phase methods simllar to those previously described $(2,4,7)$. Chloromethylated polystyrene (Merrifleld) resin crosslinked with $1 \%$ divinylbenzene was used for the symthesis of peptldes with carboxy terminal carboxylic acid functions, while p-methylbenzhydrylamine resin was used for the synthesis of carboxamide terminal peptides. $t$ Butyloxycarbonyl protection of a-amino functions was used throughout, while S-p-methylbenzy protection was used for the lablle side chain suffurs of Cys and Pen. In all cases the linear free-sulfiydry containing peptides were generated by treatment of the peptide-resin with anhydrous HF in the presence of $5 \%$ anisole and 5\% dithloethane, as has been previously described (2). Prtor to cyclization, the linear, free sulfhydrylcontaining peptides were purtfled by reverse phase-high performance liquid chromatography (RP-HPLC) on a Vydac 218TP C-18 column $(2.5 \times 22 \mathrm{~cm})$ using the solvent system $0.1 \%$ trtiluoroacetlc acld $(\mathrm{TFA})$ in $\mathrm{H}_{2} \mathrm{O} /$ $0.1 \%$ TFA in acetonitrile. A gradient of 10-50\% organic component over a course of 40 min was employed for all purfications. Disulfide containing analogs were prepared by treating an aqueous solution ( $\mathrm{pH} 8.5$ ) of the corresponding free suthydryt-containing specles with $\mathrm{K}_{3} \mathrm{Fe}(\mathrm{CN})_{6}(2)$, while dithloether-containing analogs were obtained by treating a dilute solution of the free suthydryl-containing peptide in dimethyl formamide with potassium ten-butoxide followed by addition of the appropriate alky dibromide (4). Disulfide and dithioether-containing peptides were purified by RP-HPLC as described above. Purtty of the final product peptides was assessed by analytical HPLC monitored at $280 \mathrm{~nm}$ and at $230 \mathrm{~nm}$. All peptides were $>98 \%$ pure by this measure. Analytical evaluation of the final peptides also included testing with $5,5^{\prime}-$ dithiobls-(2- 
nitrobenzoic acid) to detect the presence of free sulfindryl groups (8). Final confirmation of the putative structures was obtained by fast atom bombardment-mass spectrometry which ylelded the approprlate molecular woights for all of the peptides.

Receptor bindinq assavs. The binding assays, based on the displacement by the test compounds of radiolabelied sufentanl ( $\mu$ ligand) or DPDPE ( $\delta$ ligand) In cerebral membranes from rat brain, were performed as previously described $(9,10)$. Briefly, the assay mbture, contalning membrane suspension in $50 \mathrm{mM}$ Tris buffer $(\mathrm{pH} 7.4), 150 \mathrm{mM} \mathrm{NaCl}$, the radlolabelled llgand and the test compound, was incubated to reach binding equilibrlum (40min for assays using $0.5 \mathrm{nM}$ [ $\left.{ }^{3} \mathrm{H}\right]$ sufentanil; $60 \mathrm{~min}$ for $1.5 \mathrm{nM}\left[{ }^{3} \mathrm{H}\right] \mathrm{DPDPE}$ ) at $25^{\circ} \mathrm{C}$. Subsequently, the samples were rapidly fittered and the radioactivity on the filter determined by liquld scintilation counting. Inhibition of radiclabelled ligand binding by the test compound was computed from maximal specific blnding, determined with an appropriate excess of unlabelled sufertanil or DPDPE. IC 50 values were obtained by linear regression from plots relating inhibition of the specific binding in probit units to the $\log$ of five different ligand concentrations (9). In every case the correlation coefficient, 2 , of the logprobtt plot was higher than 0.97 .

Isolated mouse vas deferens (mud) assay, The mvd assays were performed as previously described (11). Briefly, $1.5 \mathrm{~cm}$ vas deferens segments from male, albino ICR mice were suspended in organ baths which contalned $30 \mathrm{~mL}$ of a modified Krebs' buffer $\left(118 \mathrm{mM} \mathrm{NaCl} 4.75 \mathrm{mM} \mathrm{KC,} 2.54 \mathrm{mM} \mathrm{CaCl}_{2}, 1.19 \mathrm{mM}\right.$ $\mathrm{MgSO}_{4}, 1.19 \mathrm{mM} \mathrm{KH} \mathrm{PO}_{4}, 11 \mathrm{mM}$ glucose, $25 \mathrm{mM} \mathrm{NaHCO}, 0.3 \mathrm{mM}$ pargyline $\mathrm{HC}, 0.2 \mathrm{mM}$ tyrosine, $0.1 \mathrm{mM}$ ascorblc acid, and $0.03 \mathrm{mM}$ sodium EDTA) saturated with $95 \% \mathrm{O}_{2}-5 \% \mathrm{CO}_{2}$ and kept at $37^{\circ} \mathrm{C}$. The segments were attached to strain gauge transducers and suspended between two platinum electrodes. After a $30 \mathrm{~min}$ equilibrium period, the segments were stimulated once every 10 s with pairs of pulses of $2 \mathrm{~ms}$ duration, $1 \mathrm{~ms}$ apart and at supramaximal voltage. Test compounds were evaluated for their ability to Inhibit the electrically stimulated smooth muscle contractions in this preparation. One vas deferens of each pair of vasa deferentla was studled In the presence of elther $100 \mathrm{nM}$ naltrexone or 100nM ICl-174864 and the other served as the control. $I C_{50}$ values were determined by probit analysis and values reported are the means of 3-9 determinations. Because there were no appreclable differences among the IC50 values for the control preparatlons studled with elther naltrexone or ICl-174864, the control IC50 reported for each agonist is the mean of all control values determined in experiments with both antagonists.

\section{Results}

The binding affinitles of eleven cyclic tetrapeptles to $\mu$ and $\delta$ oplold receptorg in brain membranes as determined by the ablity of the test compounds to displace the $\mu$ selective ligand $\left[{ }^{3} \mathrm{H}\right]$ sufentani and the $\delta$ selective ligand [ 3 HDPDPE (9) are Ilsted in Table I. Also provlded are the corresponding values for the reference $\mu$ ligands sufentanll and [D-Ala ${ }^{2}$, NMePhe ${ }^{4}$, Gly ${ }^{5}-\mathrm{d}$ ]enkephalln (DAGO) and the reference $\delta$ Iigand DPDPE. The initial tetrapeptides chosen for symthesis were those which had a carboxamide terminal penicillamine residue, D-Cys or D-Pen as the second residue, and which were cyclized to elther the disulfide or ethylene dithioether. Such a serles would allow direct comparison with both the disulfide-containing pentapeptides such as DPDPE as well as the highly is receptor selectlve cyclic tetrapeptide, Tyr-D-Om-PheAspNH $\mathrm{N}_{2}$, reported by Schiller and coworkers $(5,6)$ which, Ilke the ethylene dithloethers, contains a $13-$ membered ring. Unlike the analogs reponted here, however, Schiller's analog is cyclized via an amide bond between the ornithine $\delta$-amino group and the aspartic acid $\beta$-carboxylate function.

The carboxamide terminal tetrapeptides 1-7 and 9 display several interesting features. Within this series, analogs 3-6. which have a L-Pen ${ }^{4}$ residue, display rather low affinity and are essentjally devoid of receptor selecthity in the binding assay. In contrast, corresponding analogs with a D-Pen 4 residue (1,2.7 and 9) exhiblt considerable variation in both affinity and selecthity. For example, analogs 1 and I show signiflcant $\delta$ receptor selectlvity with 7 displaying considerable affinity for the $\delta$ receptor. However, analog 9 , which contains the same primary sequence $a 8 I$ but which is cyclized as the ethylene dithloether rather than the disufide, is stgnificantly $\mu$ receptor selective and displays a 2.4-fold higher affinity for $\mu$ receptor binding sites than does the prototyplcal $\beta$ ligand, DAGO. The result of aftering the ring size by two carbon atoms between analogs $I$ and 9 is a 130 -fold shift in selectlvity.

The striking selectivity shift seen between 7 and 9 as a result of altering the ring size was further explored by preparing the methylene-dithloether (actually, a dithioacetal) analog. 8. and the propylenedithioether analog. 10. Analogs 7-10 thus represent a subseries in which primary sequence is maintained 
TABLE I

Oploid Receptor Binding Profiles of Cyclic Tetrapeptides

\begin{tabular}{|c|c|c|c|c|}
\hline & & & & $\mathrm{IC}_{50}(\mu)$ \\
\hline & Analog & {$\left[{ }^{3} \mathrm{H}\right]$ sufentanil } & $\left.l^{3} \mathrm{H}\right] \mathrm{DPDPE}$ & $\mathrm{IC}_{50}(\delta)$ \\
\hline 1 & Tyr-D-Pen-Phe-D-PenNH ${ }_{2}$ & 1320 & 61 & 21.6 \\
\hline$\underline{2}$ & Tyr-D-Pen-Phe-D-PenNH ${ }_{2}$ & 1580 & 215 & 7.35 \\
\hline 3 & Tyr-D-Pen-Phe-L-PenNH ${ }_{2}$ & 188 & 103 & 1.83 \\
\hline 4 & Tyr-D-Pen-Phe-L-PenNH ${ }_{2}$ & 679 & 632 & 1.07 \\
\hline 5 & Tyr-D-Cys-Pho-L-PenNH 2 & 350 & 373 & 0.94 \\
\hline 6 & Tyr-D-Clys-Phe-L-PenNH 2 & 294 & 222 & 1.32 \\
\hline$\underline{7}$ & $\begin{array}{c}\text { Tyr-D-Cys-Phe-D-PenNH }{ }_{2} \\
S-\mathrm{CH}_{2}-\mathrm{S}\end{array}$ & 320 & 17.2 & 18.6 \\
\hline 8 & Tyr-D-Cys-Phe-D-PenNH 2 & 76 & 238 & 0.32 \\
\hline 9 & Tyr-D-Cys-Phe-D-PenNH 2 & 5.6 & 39.6 & 0.14 \\
\hline 10 & Tyr-D-Cys-Phe-D-PenNH 2 & 22.4 & 193 & 0.12 \\
\hline 11 & Tyr-D-Cys-Phe-D-PenOH & 1210 & 1.90 & 637 \\
\hline & DPDPE & 7720 & 6.44 & 1200 \\
\hline & DAGO & 13.2 & 690 & 0.02 \\
\hline & Sufentanil & 1.3 & 45 & 0.03 \\
\hline
\end{tabular}

Binding assays were performed on rat brain membrane preparations as described in Methods. Reported $I C_{50}$ values represent the mean of $1-6$ experiments run in duplicate with 5 different concentrations of each compound. The average range $(n<4)$ or standard deviation $(n \geq 4)$ for the $\mu$ and $\delta$ selective assays was $\pm 6.5 \%$ and $\pm 10 \%$, respectively $(9)$. 
While ring slze is varied from an 11-membered ring to a 14-membered ring. Increasing the ring size from the 11 -membered ing in $\underline{7}$ to the 12-membered ring of 8 increases $\mu$ receptor affinity 4-fold while decreasing $\delta$ receptor affinity by a factor of 14 (Table I). As a result, analog 8 exhibits a slight binding preference for $\mu$ opioid receptors. Increasing the ring size by an additional carbon results in a slight Improvement in $\mu$ receptor selecthity for analog 9 as compared with analog 8 . Accompaning thls improved selectlvity are impressive 6-fold and 13-fold enhancements in $\delta$ and $\mu$ receplor binding affinities, respectlvely. Further expanding the ring size to the propylene-dithioether, 10 , has little effect on selectlvity but results in a 4-fold reduction in binding affinity.

The results obtained with analogs $2,4,6$, and 9 , which contain 13-membered ring systems, are quite different from those observed for Schiller's analogous tetrapeptide. In the current series analogs 4 and 6 . which like Schiller's contain an L-amino acid in position 4, show very weak binding affinity and are essentially nonselective. Only analog 9 among those with a 13-membered ring displays $\mu$ receptor binding selectivity and this selectlvity is modest. The high $\mu$ affinity of this analog is nonetheless indlcative of a favorable conformation for $\mu$ receptor binding. That the analogs presented here differ in binding profile from those reported by Schiller is not surprising given the different steric and electronic characteristics expected for these analogs.

The significant $\delta$ receptor selectivity of analogs 1 and $I$ and the relatively high $\delta$ receptor affinity of the latter are reminiscent of earlier results in the pentapeptide penicillamine-containing enkephalin series in which carboxamide terminal analogs were observed to display $\delta$ receptor selectivity (12). Since carboxylic acid terminal enkephalin analogs are generally observed to exhibit considerably enhanced $\delta$ selectivity, the results obtained for analogs 1 and $I$ suggested that the corresponding carboxylic acid terminal analogs, particularly that of analog 7 , might lead to greatly improved $\delta$ selectivity and/or binding affinity. As shown in Table 1 this is in fact the case; analog 11 shows greatly improved $\delta$ receptor selectlvity and affinity compared to analog 7 . Indeed, analog 11 is almost as selective as DPDPE, the current standard for $\delta$ receptor selectivity, and has 3.5-fold higher affinity for $\delta$ receptors.

The oploid tetrapeptides were further evaluated on the isolated, electrically stimulated mouse vas deferens preparation and were compared to DAGO and DPDPE (Table II). Both DAGO and DPDPE were full agonists in this assay with DPDPE exhibiting approximately 15-fold higher potency than DAGO. All but three of the tetrapeptides were full agonists which produced complete inhibition of the twitch. Analogs $2, \underline{4}$, and 10 were partlal agonists which produced maximal inhibltions of $85.1 \pm 2.1 \%, 65.8 \pm 3.8 \%$, and $91.9 \pm 2.0 \%$, respectively. The most potent in this serles in inhibiting the twitch was analog 11 which was essentlally equipotent with DPDPE. Analog 9 had about one-half the potency and analog $\overline{8}$, about one-eighth the potency of DPDPE. All other analogs were less potent than DAGO as agonists in this preparation, and the partial agonists, analogs 2 and $\underline{4}$ were the least potent of the serles. Because of the much lower potency of analog 2 on the vas deferens than in the binding assay, this peptide was evaluated as a possible antagonist, however no such activity was observed.

In onder to determine the types of opioid receptors which mediate the agonist activity of the tetrapeptide analogs, complete concentration-effect relationships were determined in the presence and absence of two opiold antagonists, naltrexone, which is somewhat more selective for $\mu$ receptors than for $\delta$ receptors in the mouse vas deferens (11), and $\mathrm{ICl}-174864$, which is a highly selective antagonist at $\delta$ oploid receptors and is virtually devoid of activity at $\mu$ receptors (13). Naltrexone (100nM) caused a 27.4-fold shift to the right in the DAGO concentratlon-ffect curve which is typical of those shifts seen with highly selective $\mu$ receptor

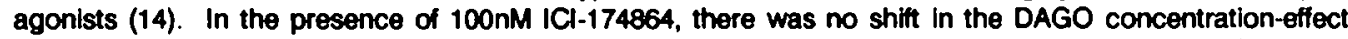
curve. In contrast, naltrexone produced a smaller shift in the DPDPE concentration-effect curve (7.1-fold), and $\mathrm{ICl}-174864$ significantly shifted the DPDPE concentration-effect curve to the right (2.8-fold).

Three of the tetrapeptide analogs appeared to be even more selectlve than DPDPE for $\delta$ receptors in the mouse vas deferens. The shifts produced by $100 \mathrm{nM}$ naltrexone and $100 \mathrm{nM} \mid \mathrm{Cl}-174864$ were 5.7 - and 4.5fold for analog 11, 3.2 and 4.8-fold for analog 1, and 3.9- and 4.0-fold for analog 7 respectlvely. These results are in qualitative agreement with the displacement studies which found these analogs to exhibit the highest $\delta$ binding selectivity in the series. Two of the tetrapeptide analogs appeared to act only on $\mu$ receptors in the vas deferens. The shifts produced by $100 \mathrm{nM}$ naltrexone and $100 \mathrm{nM} \mathrm{ICl}-174864$ were $5.2-$ and 1.0-fold for analog 10 and 41.3- and 1.2 fold for analog 9. Again these results are In agreement with the displacement results which established analogs 9 and 10 as having the highest $\mu$ binding selecthity in thls 
TABLE \|

Tetrapeptide Potencles in the Mouse Vas Deferens Preparation in the Presence and Absence of Oplotd Amtagonlsts

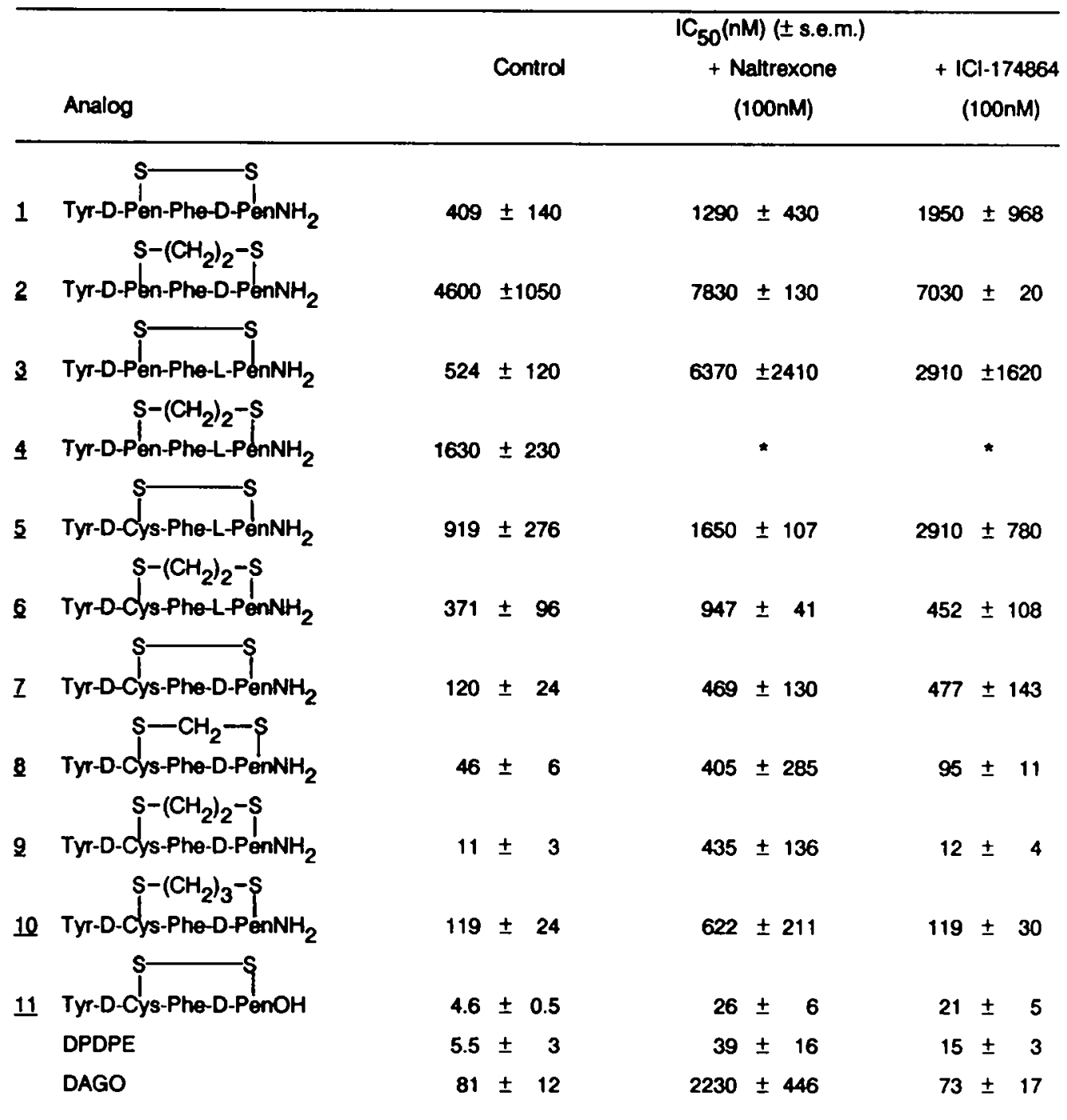

* Due to low potency and large shift by both antagonists, accurate $I C_{50}$ values could not be determined. Each reported $I_{50}$ value represents the mean of 3-9 determinations. 
serles. Both antagonists shifted responses to analog 4 to such a degree that $1 \mathrm{C}_{50}$ values could not be reliably determined, while nether antagonist produced an appreciable shift in the concentration-efiect curve of analog 2. Both of these analogs were partial agonists of extremely low potency. The interactions with the two antagonists suggested that the remaining tetrapeptides had significant activity at both $\mu$ and $\delta$ receptors, which, again, is conslstert with the results of the binding assays.

\section{Discussion}

As noted above analogs 3-6, which have a carboxy terminal L-Pen residye, have low oplold binding affinity and are essentially nonselectlve. In contrast, the corresponding D-Pen analogs display significant receptor selectivity and, except for 2 , have higher binding affinities. This is particularly evident in analog $\mathbf{Z}$, which has $\mu$ receptor binding affinity like that of analog 5 but which has $\delta$ receptor binding affinity 22-fold higher than 5. Simlarty, analog 9 has 5.6 and 53-fold higher affinity than analog 6 for $\delta$ and $\mu$ receptors, respectlvely. Potencles in the mud assay parallel the binding results, wh analog 7 exhibiting 7.7-told higher potency than 5 and analog 9 displaying 35 -fold higher potency than 6 . Further, while analogs 5 and 6 are relatively nonselective based on antagonist shifts in the mud, analog $I$ appears to be selective for $\delta$ and analog 9, selective for $\mu$ receptors in this preparation. These findings suggest a requirement for a carboxyterminal D-amino acid for optimal binding to both $\delta$ and $\mu$ receptors in this serles, a more stringent condition than is found in the penicillamine-containing pentapeptide serles (1-3). Such a divergence of effect due to attering the configuration of the carboxy terminal residue may be due to the increased rigidity resulting from the elimination of the glycine residue in the tetrapeptide series. In the pentapeptide serles this flexible glycine residue has been suggested to serve as a means of achieving a similar topography for the various analogs in the series (15). The lack of such a fiexible hinge In the tetrapeptide serles eliminates much of this conformational compensation.

The changes in receptor binding selecthity observed among analogs $7-10$, In which the ring size is varied from 11- to 14-membered without altering the primary sequence, also reflect the importance of conformation on pharmacological activity. As was seen in a series of dithioether-containing pentapeptides dertved from DPDPE and DPLPE, increasing the ring size in the tetrapeptide series diminishes $\delta$ receptor selecthity (4). In the pentapeptide serles, however, this resulted from a large decrease in $\delta$ receptor affinity whth little effect observed on $\mu$ receptor affinity. By contrast, in analogs $Z-10$ increasing ring size leads to greatly enhanced $\mu$ receptor binding affinity (and consequent $\mu$ receptor selectivity), particularly in 9 , while $\delta$ receptor affinity is more variable. Nonetheless, the general trend previously observed, namely that more compact conformations tend to favor $\delta$ receptor binding selectivity, is supported by the data presented here. The observed changes In binding selectivities in analogs $7-10$ are in agreement wht the behavior of these analogs in the mud preparation. As seen from the antagonist shifts presented in Table II, analog $\underline{7}$ displays high $\delta$ selectivity in the mud while 9 and 10 act primarlly on $\mu$ receptors in this assay.

We have previously proposed that the high $\delta$ receptor selectlvity of DPDPE is due in part to adverse steric Interactions between the $\beta, \beta$-dimethyt substhuents of the Pen ${ }^{2}$ residue and the receptor binding slte which decrease binding affinity to $\delta$ and particularly to $\mu$ receptors $(4,15)$. Further evidence is seen in the curremt series from a comparison of binding affinities of analog 2 with analog 9 . In these ethylene-dithioether analogs, analog 2, which has a D-Pen residue in position 2, has 5.4-fold and 280 -fold lower affinity at $\delta$ and $\mu$ receptors, respectively than does analog 9 . Thls result, which is similar to that observed with the pentapeptides, DPDPE and DCDPE, reflects adverse steric interactlons of the D-Pen ${ }^{2} \beta, \beta$-dimethyl groups particularly at $\mu$ receptor binding stes. It should be noted that the disulfide-containing analogs 1 and 7 show a much less impressive steric effect due to the side chain of residue 2 . In this case the $\beta, \beta$-dimethyls of residue 2 in analog 1 resut in approximately 4 -fold reductions in binding affinity to both $\delta$ and $\mu$ receptors. In both analogs, $\mu$ receptor binding affinities are low suggesting that these more compact structures may lead to adverse steric (or other) interactions with the $\mu$ receptor which are not observed in more extended structures such as 9.

The design of analog 11 was, as indicated above, straightforward given the observed $\delta$ receptor selecthity and potency of the carboxamide terminal analog 7 . The resutting high selectivity (similar to that of DPDPE) and high $\delta$ affinity (3.5 fold higher than that of DPDPE) displayed by analog 11 are impressive. The improved affinity may prove to be useful for in vivo experiments. Perhaps of greater significance, analog 11 provides an important tool for elucidating the optimal ligand conformation for $\delta$ opioid receptor binding. Since both 11 and DPDPE must assume similar conlormations at the $\delta$ binding site, comparlsons of possible 
conformations for these two compounds should allow the elimination of unlikely binding conformations and greatly facilitate the determination of the optimal ligand conformation at the $\delta$ opioid receptor.

\section{Acknowledgements}

These studies were supported by USPHS grants DA 03910 (HIM) and DA 00254 (HIM, FM, CBS). The expent technical assistance of Mary J. Clark Is gratełully acknowledged.

\section{References}

1. H.I. MOSBERG, R. HURST, V.J. HRUBY, J.J. GALLIGAN, T.F. BURKS, K. GEE, and H.I. YAMAMURA, Lite Scl. 32, 2656-2659 (1983).

2. H.I. MOSBERG, R. HURST, V.J. HRUBY, K. GEE, H.I. YAMAMURA, J.J. GAUIGAN, and T.F. BURKS, Proc. Natl. Acad. Scl. $90,5871-5874$ (1983).

3. H.I. MOSBERG, R. HURST, V.J. HRUBY, J.J. GALUGAN, T.F. BURKS, K. GEE, and H.I. YAMAMURA in Pepeldes: Structure and Function . Eds. V.J.Hruby and D.H.Rich, Pierce Chemical Co., Rockford, IL pp.279-282 (1983).

4. H.I. MOSBERG, J.R. OMNAAS, and A. GOLDSTEIN. Mol. Pharmacol. 31, 599-602 (1987).

5. P.W. SCHILLER, T.M.D. NGUYEN, C. LEMIEUX, and L.A. MAZIAK, in Peptides: Structure and Function , Eds. C.M.Deber, V.J.Hruby, and K.D.Kopple, Plerce Chemical Co., Rockford, IL pp483-486 (1985).

6. P.W. SCHILLER, T.M.-D. NGUYEN, LA. MAZIAK, B. C. WILKES, and C. LEMIEUX, J. Med. Chem. 30 , 2094-2099 (1987).

7. H.I. MOSBERG and J.R. OMNAAS, J. Amer. Chem. Soc. 107, 2986-2987 (1985).

8. G.L. ELLMAN, Arch. Blochem. Blophys. 82, 70-77 (1959).

9. M.J. CLARK, B.D. CARTER, and F. MEDZIHRADSKY, EUr. J. Pharmacol. 148, $343-351$ (1988).

10. F. MEDZIHRADSKY, P.J. DAHLSTROM, J.H. WOODS, S.V. FISCHEL, and S.E. MITSOS, Life SCI. 34 , 2129-2138 (1984).

11. C.B. SMITH, NIDA Research Monoaraph Series No, 76: Problems of Drug Dependence 1986, pp 288-294 (1987).

12. H.I. MOSBERG, R. HURST, V.J. HRUBY, J.J. GALLIGAN, T.F. BURKS, K. GEE, and H.I. YAMAMURA, Blochem. Blophys. Res. Commun. 106, 506-512 (1982).

13. R. COTTON, M.G. GILES, L MILLER, J.S. SHAW, and D. TIMMS, Eur. J. Pharmacol. 27, 331-332 (1984).

14. C.B. SMITH, L BENNETT-KELLY, and J.H. WOODS, Neuropeptides 5, 161-164 (1984).

15. H.I. MOSBERG, Int. J. Peptlde Protein Res. 299, 282-288 (1987). 